\title{
Improving the Efficiency of Solar Photovoltaic Cell by Decreasing Surface Temperature
}

\author{
K. Jaiganesh, P. Arulkumar, S. Karunakaran, Md. Asif, N. Srinivas
}

\begin{abstract}
Supply of energy is able to meet the increasing demand of today's people, which is major causes faced by world. The shortage of power can be reduced by using renewable energy resources. There are many renewable energy resources like wind, tidal and biomass energy, solar energy. The most significant form of renewable source is solar energy. It has undergone a research and development in the recent years and still it is developing. Solar photovoltaic cell is device used in solar energy conversion. It converts forthrightly electrical energy from the sunlight. The efficiency of $P V$ cell is disturbed when rise in working temperature. Temperature on the panel is inversely proportional to the power generation. The main problem met by solar cell is temperature rise. Due to this temperature the energy conversion is low. By decreasing the temperature on the surface of $P V$ panel to enhance the electric efficiency.

So, in present-day different cooling methods have been projected and verified experimentally. Several techniques have been tried, mostly based on active water and air cooling, as these are simple techniques. The main objective of this system is to increase the solar panel efficiency using water cooling method of the panel gets cooled by exchange temperature.
\end{abstract}

Keywords: Solar PV, Cell Temperature, efficiency improvement

\section{INTRODUCTION}

Energy shortage is the global difficulty in front of all. Environment pollution and global warming is the another problem due to conventional power plants, it is very much essential to shift into an alternate source to generate power except fossil fuel consumption. Fossil fuels turn to exhaust in following few decades, hydroelectric plants are be influenced by yearly rainfall on the particular area also wind power generation based on environment fluctuations. Solar energy is the only choice for sustainable energy source. The complete existing and forthcoming requirements of power demand is fulfilled by solar energy.

Revised Manuscript Received on December 30, 2019.

* Correspondence Author

Dr.K.Jaiganesh*, Professor, EEE, Vardhaman College of Engineering, jaiganesh@vardhaman.org

Dr.P.Arulkumar, Professor/EEE, Balaji Institute of Technology and Science, arulkumarme@gmail.com

Dr. S.Karunakaran, Professor, ECE, Vardhaman college of Engineering, s.karunakharan@vardhaman.org

Md. Asif , Associate Professor/EEE, Vardhaman College of Engineering. asif_eee@vardhaman.org

N. Srinivas, Asst. Professor/EEE, Vardhaman College of Engineering. nakkasrinu@gmail.com

(C) The Authors. Published by Blue Eyes Intelligence Engineering and Sciences Publication (BEIESP). This is an open access article under the CC BY-NC-ND license (http://creativecommons.org/licenses/by-nc-nd/4.0/)
Most solar cells are a safe and clean way to produce electricity; they can also be recycled to reduce waste. While

generating electrical power, solar cells do not require a fuel source, other than the sun, and do not produce emissions of any kind. Normally, solar cells use a small amount of water, which is used to clean the solar modules also specifically in hot regions for reduce the heat on the panel [1]. In comparison, a coal power plant produces 36 times more carbon di oxide and uses 41 times more water. Electricity generated from a solar thermal system uses over 100 times more water than solar cells; and hydroelectric losses are 200 times more than solar due to the evaporation from the reservoir.

Obviously there are several benefits to producing more electrical energy by means of solar cells. Two of the primary limitations of the future growth of solar energy are the installation cost and the cost of the available storage options, to store the energy for later use.

We all are using sun's energy since years for several purposes but in recent times we have started using the sun's energy for producing power. Around $70 \%$ of the light gets returned back to space and only the left over $30 \%$ light is enough to meet up our needs. We develop adequate energy from the sun that it could meet up our power demands, if harness it properly. Cooling or temperature maintenance on solar PV will improve the efficiency of it [2, 3]. The change in temperature between solar cell internal resistance and external resistance of load also create temperature effect on solar PV [4]. So cooling of solar PV is very much important to improve the efficiency [5].

\section{DESIGN TECHNIQUE}

\section{A. Cooling scheme}

The continuous cooling on the Photovoltaic cells will improve the performance of the system. The temperature of the PV panel is goes up to $75^{\circ} \mathrm{C}$ and above (without cooling) and $25^{\circ} \mathrm{C}$ (during cooling). The permissible temperature of the Photovoltaic panel is considered as $35^{\circ} \mathrm{C}$, the process of cooling on panel starts while the temperature above $35^{\circ} \mathrm{C}$. The water is pumped into heat exchanger below the PV panel up to the temperature reduced below $25^{\circ} \mathrm{C}$. The change in temperature $\Delta \mathrm{Tw}$ is the difference inlet and outlet water temperature.

The difference is considered that $\Delta \mathrm{Tw}-\Delta \mathrm{Tg}=10^{\circ} \mathrm{C}$. This is decided that as the rate of flow rises which reduce the time in cooling of panel. The pump activates in that way to pumps water into the heat exchanger, which results in cooling of solar PV cell. 


\section{B. Block Diagram}

The block diagram is shown in figure. 1 which it consists of solar PV cell, Arduino, dc motor and pump, battery source, container, hot water tank, overhead tank, temperature sensor. The temperature sensor (LM35) sense the temperature and sends analog output to the Arduino. Arduino works by dumping code in to it. In this code it has operating temperature. If panel temperature is greater than specified temperature the motor will run and it starts pimping water on to the solar cell. In order to run motor it require $12 \mathrm{v}$ battery.

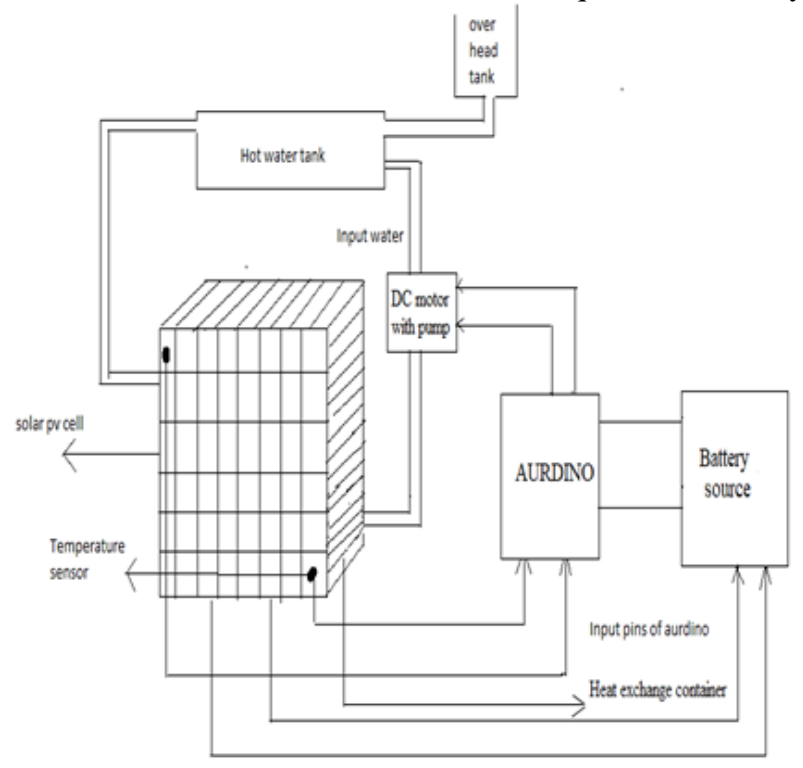

Fig.1 Overall System Block Diagram

\section{Working of Cooling System}

The heat produced on the panel due to solar radiation, according to the Standard Test Condition (STC) of the panel, the maximum efficiency obtainable on the panel at the temperature of $25^{\circ} \mathrm{C}$. Each and every ${ }^{\circ} \mathrm{C}$ of temperature increment $0.485 \%$ power generation reduced. This cooling system is used to maintain the temperature to enhance the power generation. LM35 is a temperature sensor which is fixed above the solar panel. This will sense the temperature of the panel which is interfaced with the Arduino as exposed in fig. 1

Arduino compare the temperature of set value and actual value, if the difference above $10^{\circ} \mathrm{C}$. It starts the water pump which is installed.

The water is then pumped by the water pump through the hose pipes to the PVC pipe rails which drips water on to the panel and cools the panel. As the temperature reaches less than $35^{\circ} \mathrm{C}$ the motor will turned off. Solar panel is placed above the heat exchange container when the temperature is above the minimum temperature the motor pump the water to the container and heat exchange will be happen. The water becomes hot and hot panel gets cooled .Then the hot water again sent back to the same heat exchanger.

\section{Temperature Control}

Here the PV panel high temperature can be controlled with help of heat exchanger. The temperature of photovoltaic panel can be known by the LM35 temperature sensor, this sensor sense the temperature of the panel and send the signal to the Arduino then Arduino checks the temperature if temperature is above the temp Min then it sends signal to the electric pump then the pump activates the flows the water through the heat exchange container. In this way the panel temperature can be controlled.

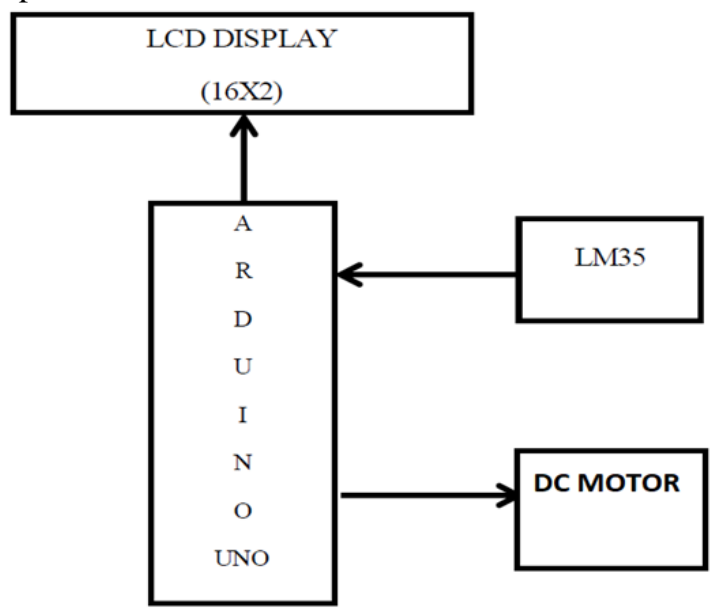

Fig .2 Temperature Controller with Arduino

The temperature controller with Arduino and DC motor is shown in above figure.2. It consist of LCD, Arduino board (UNO), LM35 temperature sensor, DC motor. Now Arduino is advanced amongst all electronic circuits, so Arduino board used for control the speed of motor. The proposed system is designed to detect the temperature of the panel and send that information to the Arduino board. Then the Arduino board executes the difference of existing temperature of the PV panel with set temperature based on the inbuilt program in Arduino. The output from the Arduino is given to the LCD then the associated information is displayed in it.

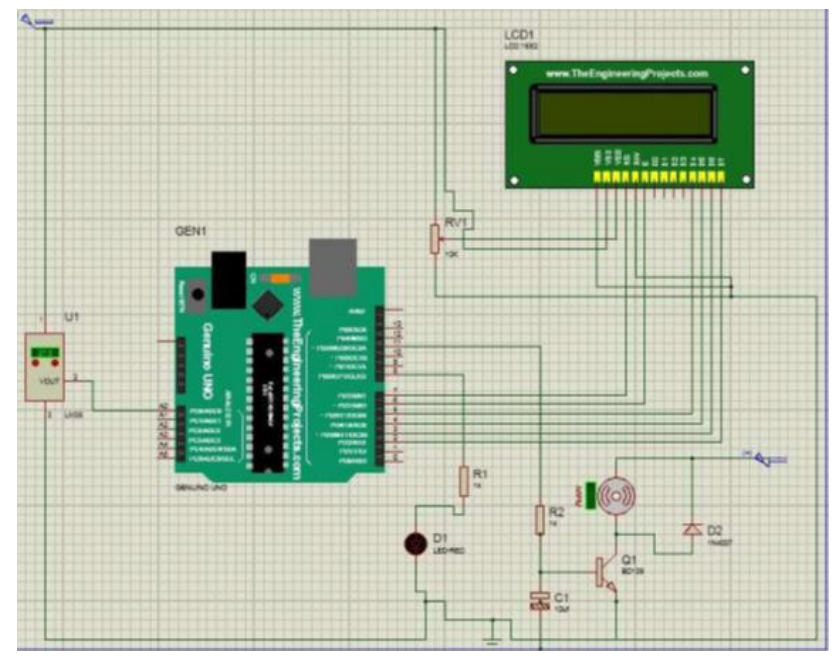

Fig.3 Temperature-Based Pump Motor Speed Control using Arduino

\section{E. Temperature sensor}

LM35 it is a temperature sensor it is shown in figure 40. It consist of three pin first pin is connected the supply voltage $5 \mathrm{~V}$ supply. 2nd pin gives the analog output Ao which is connected to the aurdino.3rd pin is connected to the ground.

Published By:

Blue Eyes Intelligence Engineering

DOI: 10.35940/ijeat.B3854.129219

Journal Website: www.ijeat.org 


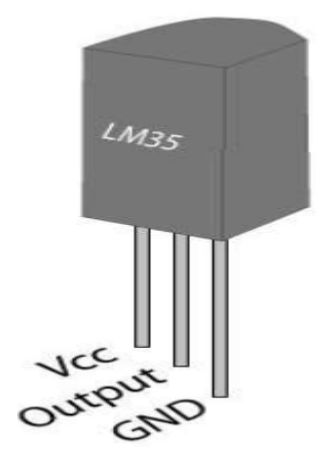

Fig.4 Pin detail of LM35

First the LM35 temperature sensor will sense the temperature. If the temperature is below the $30^{\circ} \mathrm{C}$ then the motor will be off. If it is greater than the $30^{\circ} \mathrm{C}$ then the motor will on. It again checks the temperature depends upon the temperature value the motor will run at that speed. It is shown in the figure 4. Flow chart for temperature control is shown in figure 5 .

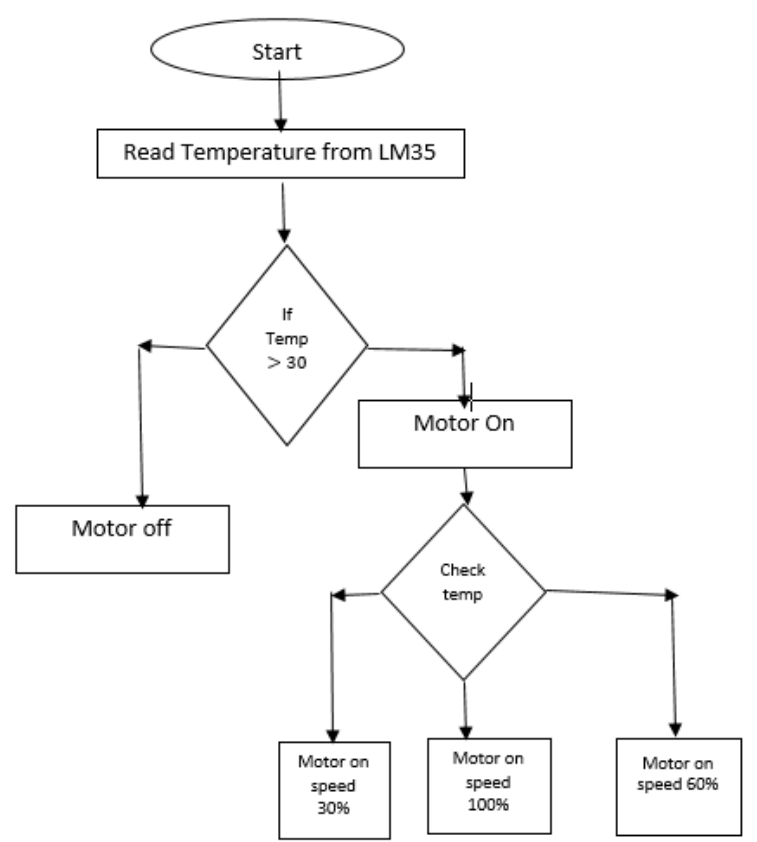

Fig. 5 Flow chart for temperature control

\section{SOURCE CODE}

\#include <LiquidCrystal.h>

LiquidCrystal lcd(7,6,5,4,3,2);

int tempPin = A0;

int motor $=11$;

int led = 8;

int temp;

int tempMin = 25;

int tempMax = 35;

int motorSpeed;

int motorLCD;

void setup()

\{

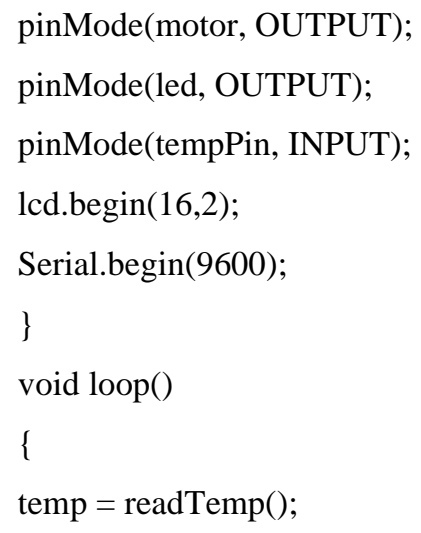




\section{Improving the Efficiency of Solar Photovoltaic CellbyDecreasingSurface Temperature}

\section{WARM WATER LOADING TANK}

The tank which is used to store the warm water is called as storage tank for household applications. Related to other resources, water accumulate extra heat per unit of weight. Water cost is low and it has non-toxic property. The stored heat is retained for few days in an insulated tank, reducing fuel costs. After some years corrosion on tank may create leakage on it.

\section{RESULT AND DISCUSSION}

Table - I PV Panel Reading at 12.30 PM

Voltage
(v)
Current(I) Power(W)

\begin{tabular}{|l}
\hline 32 \\
\hline 30.5 \\
\hline
\end{tabular}

0.38

0.38
12.236

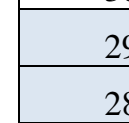

0.7

.79

24.095

29.7

1.25

37.125

$$
26.9
$$

1.63

.63

46.455

\begin{tabular}{|c|c|c|}
\hline 25.4 & 2.44 & 61.976 \\
\hline 24.3 & 2.68 & 65.124 \\
\hline 23.5 & 2.86 & 67.21 \\
\hline 22.5 & 3.06 & 68.85 \\
\hline 21.1 & 3.37 & 71.107 \\
\hline 20.4 & 3.53 & 72.012 \\
\hline 18.1 & 3.79 & 68.599 \\
\hline 14.8 & 4.02 & 59.496 \\
\hline 11.2 & 4.56 & 51.072 \\
\hline 9.2 & 5.25 & 48.3 \\
\hline 5 & 5.9 & 33 \\
\hline 0.01 & 6.8 & 0.068 \\
\hline
\end{tabular}

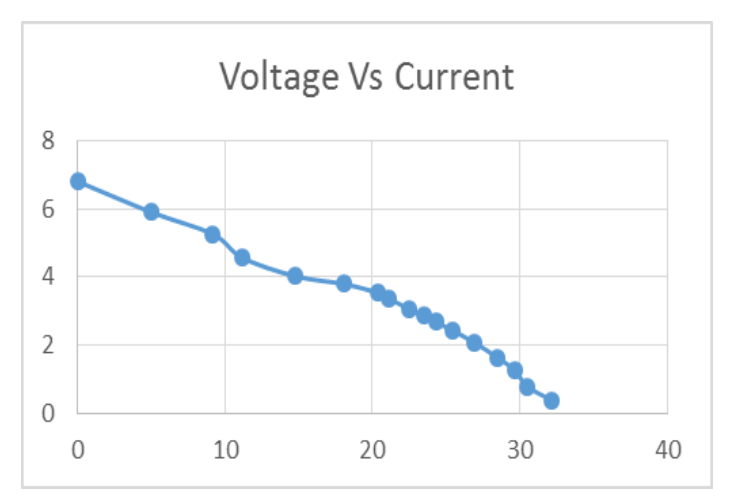

Fig.6.Output wave form

At $12: 30 \mathrm{pm}$ these are the voltage and current obtained before cooling. Open circuit voltage is $29.2 \mathrm{~V}$ and Isc is equal to $4.61 \mathrm{~A}$. The voltages and current readings at $12.30 \mathrm{PM}$ is shown in above table-I.

In the below table II gives the detail relation between the temperature of the PV panel and the operation of pump motor for cooling the PV panel. Whenever the temperature goes above set value then immediately pump motor start to supply water to the cooling system. Which will maintain the temperature within the set value.

Table II Motor Operation under Different Temperature

\begin{tabular}{|c|c|c|c|c|}
\hline Time & $\begin{array}{c}\text { Temp } \\
\text { in }{ }^{\circ} \mathrm{C}\end{array}$ & $\begin{array}{c}\text { Temp in }{ }^{\circ} \mathrm{C} \\
\text { without } \\
\text { motor } \\
\text { operation }\end{array}$ & $\begin{array}{c}\text { Motor } \\
\text { status }\end{array}$ & $\begin{array}{c}\text { Temp in }{ }^{\circ} \mathrm{C} \\
\text { with motor } \\
\text { operation }\end{array}$ \\
\hline 9.00am & 33.2 & 33.2 & off & 33.2 \\
\hline $10.00 \mathrm{am}$ & 45.9 & 45.9 & on & 36 \\
\hline $11.00 \mathrm{am}$ & 52.6 & 52.6 & on & 35.2 \\
\hline $12.00 \mathrm{noon}$ & 58.2 & 58.2 & on & 34 \\
\hline $13.00 \mathrm{pm}$ & 63.5 & 63.5 & on & 36 \\
\hline $14.00 \mathrm{pm}$ & 68.8 & 68.8 & on & 37.5 \\
\hline $15.00 \mathrm{pm}$ & 63.5 & 63.5 & on & 35.2 \\
\hline $16.00 \mathrm{pm}$ & 54.5 & 54.5 & on & 36 \\
\hline $17.00 \mathrm{pm}$ & 32.5 & 32.5 & off & 32.5 \\
\hline
\end{tabular}

\section{CONCLUSION}

The panel efficiency is improved by continuous flow of water based on the temperature difference by the Arduino and controller as shown in table II. The heat collected from PV panel is circulated through the heat exchanger which is stored in insulated tank. The hot water stored in the tank can be used for household applications.

\section{REFERENCES}

1. Moharram, Khaled A., M. S. Abd-Elhady, H. A. Kandil, and H. El-Sherif. "Enhancing the performance of photovoltaic panels by water cooling." Ain Shams Engineering Journal 4, no. 4 (2013): 869-877.

2. Jaiganesh, K., and K. Duraiswamy. "Experimental study of enhancing the performance of PV panel integrated with solar thermal system." International Journal of Engineering and Technology 5, no. 4 (2013): 3419-3426.

3. Gardas, Bhaskar B., and M. V. Tendolkar. "Design of cooling system for photovoltaic panel for increasing its electrical efficiency." International J Mechanical Prod Engineering 1 (2012): 63-67.

4. Han, Kibong, Dongchan Shin, and Yongho Choi. "Efficiency of Solar Cell at Relatively High Temperature." Int. J. Emerging Technol. Adv. Eng 2 (2012): 607-610.

5. Jaiganesh, K., and K. Duraiswamy. "Improving the Power Generation from Solar PV Panel Combined with Solar Thermal System for Indian Climatic Condition." International Journal of Applied Environmental Sciences (ISSN 0973-6077). Volume 6 (2013).

\section{AUTHORS PROFILE}

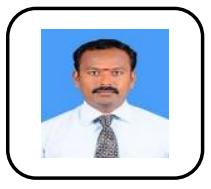

Dr. K. Jaiganesh, working as a Professor in the Department of EEE at Vardhaman College of Engineering (Autonomous) Hyderabad.

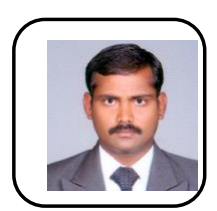

Dr.P.Arulkumar, obtained his B.E degree from Periyar University in 2002, M.E from Anna University in 2004 and received his Ph.D in Power Electronics from PRIST University in 2017. 


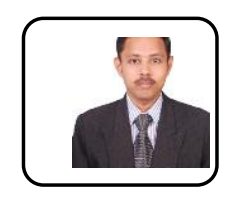

Dr.S.Karunakaran, Professor, Department of ECE in Vardhaman College of Engineering, (Autonomous) Hyderabad

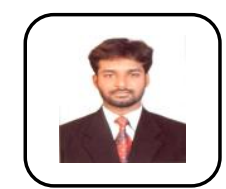

Md. Asif, Associate Professor, Department of EEE, Vardhaman College of Engineering, Hyderabad

N. Srinivas, Assistant Professor, Department of EEE, Vardhaman College of Engineering, Hyderabad. 